\title{
COVID-19 as cause of viral sepsis: A Systematic Review and Meta-Analysis
}

Eleni Karakike ${ }^{1}$, Evangelos J. Giamarellos-Bourboulis ${ }^{1}$, Miltiades Kyprianou ${ }^{1}$, Carolin Fleischmann-Struzek ${ }^{2,3}$, Mathias W. Pletz ${ }^{2}$, Mihai G. Netea ${ }^{4,5}$, Konrad Reinhart*6 Evdoxia Kyriazopoulou*1

*equal contribution

${ }^{1} 4^{\text {th }}$ Department of Internal Medicine, National and Kapodistrian University of Athens, Medical School, Athens, Greece;

${ }^{2}$ Institute for Infectious Diseases and Infection Control, Jena University Hospital, Jena, Germany;

${ }^{3}$ Center for Sepsis Control and Care, Jena University Hospital, Jena, Germany;

${ }^{4}$ Department of Internal Medicine and Center for Infectious Diseases, Radboud University, Nijmegen, The Netherlands;

${ }^{5}$ Immunology and Metabolism, Life \& Medical Sciences Institute, University of Bonn, Bonn, Germany;

${ }^{6}$ Department of Anesthesiology and Operative Intensive Care Medicine (CCM, CVK), Charité Universitätsmedizin Berlin, corporate member of Freie Universität Berlin, Humboldt-Universität zu Berlin, and Berlin Institute of Health, Berlin, Germany.

\section{Corresponding Author}

Evangelos J. Giamarellos-Bourboulis, MD, PhD

$4^{\text {th }}$ Department of Internal Medicine, ATTIKON University General Hospital

1 Rimini Street 12462 Athens, Greece

Tel: +302105831 994, Fax: +302105326446

E-mail: egiamarel@med.uoa.gr 


\section{KEY POINTS}

Question: What is the prevalence of viral sepsis by Sepsis-3 definition among hospitalized patients with COVID-19?

Findings: In this systematic review and meta-analysis, we systematically reviewed published literature for evidence of organ failure in COVID-19, to estimate the prevalence of viral sepsis in this setting, by means of SOFA score calculation. The prevalence of sepsis in COVID-19 was $39.9 \%\left(95 \% \mathrm{Cl}, 35.9-44.1 ; \mathrm{I}^{2}, 99 \%\right)$.

Meaning: This is the first study to address the burden of viral sepsis in hospitalized patients with COVID-19, a highly heterogenous infection ranging from asymptomatic cases to severe disease leading to death, as reflected in the high heterogeneity of this study. 


\section{ABSTRACT}

Importance COVID-19 is a heterogenous disease most frequently causing respiratory tract infection but in its severe forms, respiratory failure and multiple organ dysfunction syndrome may occur, resembling sepsis. The prevalence of viral sepsis among COVID-19 patients is still unclear.

Objective We aimed to describe this in a systematic review.

Data sources MEDLINE(PubMed), Cochrane and Google Scholar databases were searched for studies reporting on patients hospitalized with confirmed COVID-19, diagnosed with sepsis or infection-related organ dysfunctions or receiving organ replacement therapy.

Study selection Eligible were full-text English articles of randomized and nonrandomized clinical trials and observational studies reporting on patients with confirmed COVID-19, who are diagnosed with sepsis or have infection-related organ dysfunctions. Systematic reviews, editorials, conference abstracts, animal studies, case reports, articles neither in English nor full-text, and studies with fewer than 30 participants were excluded.

Data extraction and synthesis All eligible studies were included in a narrative synthesis of results and after reviewing all included studies a meta-analysis was conducted. Separate sensitivity analyses were conducted per adult vs pediatric populations and per Intensive Care Unit (ICU) vs non-ICU populations.

\section{Main outcomes and measures}

Primary endpoint was the prevalence of sepsis using Sepsis-3 criteria among patients with COVID-19 and among secondary, new onset of infection-related organ dysfunction. Outcomes were expressed as proportions with respective 95\% confidence interval $(\mathrm{Cl})$. 
Results Of 1,903 articles, 104 were analyzed. The prevalence of sepsis in COVID-19 was $39.9 \%\left(95 \% \mathrm{Cl}, 35.9-44.1 ; \mathrm{I}^{2}, 99 \%\right)$. In sensitivity analysis, sepsis was present in $25.1 \%\left(95 \% \mathrm{Cl}, 21.8-28.9 ; \mathrm{I}^{2}\right.$ 99\%) of adult patients hospitalized in non-IntensiveCare-Unit (ICU) wards (40 studies) and in 83.8 (95\% Cl, 78.1-88.2; I²,91\%) of adult patients hospitalized in the ICU (31 studies). Sepsis in children hospitalized with COVID-19 was as high as $7.8 \%\left(95 \% \mathrm{Cl}, 0.4-64.9 ; \mathrm{I}^{2}, 97 \%\right)$. Acute Respiratory Distress Syndrome was the most common organ dysfunction in adult patients in nonICU (27.6; 95\% Cl, 21.6-34.5; I', 99\%) and ICU (88.3\%; 95\% Cl, 79.7-93.5; I', 97\%)

Conclusions and relevance Despite the high heterogeneity in reported results, sepsis frequently complicates COVID-19 among hospitalized patients and is significantly higher among those in the ICU.

PROSPERO registration number: CRD42020202018. No funding.

Keywords viral sepsis; COVID-19; organ dysfunction; organ replacement; SOFA. 


\section{INTRODUCTION}

COVID-19, caused by the severe acute respiratory syndrome coronavirus (SARS-CoV)-2, is recognized as a pandemic, affecting 230 countries with $54,771,888$ confirmed cases and 1,324,249 deaths worldwide, as of 17 November 2020 (1). Several patients are complicated by respiratory insufficiency and they are in need for mechanical ventilation (2). First reports of patients in Wuhan described in addition of lung disease the presence of other organ failures including acute kidney injury, liver dysfunction, coagulopathy, confusion and shock; such an involvement resembles the systemic counterparts of bacterial and viral sepsis (3-5). The current Sepsis-3 definitions define sepsis as a life-threatening organ dysfunction due to the dysregulated host response to an infection. The same definitions introduce the Sequential Organ Failure Assessment (SOFA) score as a measure of organ dysfunction (6). According to World Health Organization (WHO), manifestations of sepsis and septic shock can be also the fatal frequent pathway of infections with highly transmissible pathogens of public health concern such as avian and swine influenza viruses, as well as corona viruses (7). Severe respiratory failure of COVID19 is accompanied by complex immune dysregulation of the host (8). As a consequence, all elements of the new Sepsis-3 definition may apply for COVID-19 i.e. life-threatening organ dysfunction, dysregulated host response, and viral infection (9).

With this in mind, we systematically reviewed published evidence for COVID19 as a cause of viral sepsis using the SOFA score as a classification tool. In parallel the prevalence of different organ dysfunctions, the need for ICU admission, the association of sepsis presence with mortality and the presence of alterations of inflammation and coagulation markers were analyzed. 


\section{METHODS}

\section{Search strategy and selection criteria}

The literature search and review process were conducted according to the Preferred Reporting Items for Systematic reviews and Meta-Analyses (PRISMA) statement (10), based on a pre-specified protocol (PROSPERO database registration number: CRD42020202018).

The search of the peer-reviewed medical literature was conducted across MEDLINE (PubMed), Cochrane and Google Scholar databases using the following terms: "COVID-19" or "SARS-CoV-2" and "sepsis", "organ failure", "organ dysfunction". Detailed search strategy is provided in Supplement. Inclusion criteria comprised randomized and non-randomized clinical trials and observational studies reporting on the proportion of patients diagnosed with confirmed COVID-19, who were diagnosed with sepsis, had infection-related organ dysfunctions, or received organ replacement therapy (dialysis, mechanical ventilation, extracorporeal membrane oxygenation [ECMO], liver replacement therapy). Sepsis was defined i) as sepsis according to Sepsis-3 definitions (i.e. any at least two-point SOFA score at presentation or any at least two-point-increase of the baseline SOFA score during hospitalization; ii) as severe sepsis according to Sepsis $1 / 2$ criteria; or iii) by relevant ICD codes $(7,11,12)$. Only articles published as full text in English were included, while systematic reviews, editorials, conference abstracts, animal studies, case reports, articles not written in English or not providing full-text, and studies with fewer than 30 participants were excluded.

The literature search was conducted on August 27, 2020 and repeated on

October 3, 2020 by two independent authors (E.Ky and E.Ka). The same reviewers assessed all articles by title, abstract and complete text to find those meeting the 
predefined eligibility criteria and extracted information as follows: first author name, country of origin, publication year and month, study design, total number of patients reported, criteria for enrollment in the study, number of patients presenting sepsis, new onset organ dysfunction, organ support/replacement therapy, number of patients requiring ICU treatment, ICU discharge, hospital discharge and 30-day mortality. Any controversies were resolved by a third reviewer (E.J.G.B). All authors of the selected articles were contacted to provide relevant data.

Each study was evaluated by both reviewers in terms of quality of the provided data with the Methodological index for non-randomized studies (MINORS) (13). An additional assessment of certainty in extraction of the primary endpoint was made, rated by means of a four-star scale, from zero (one star) to high uncertainty (four stars), in order to assess causes for potential heterogeneity. Articles providing the exact number of patients fulfilling Sepsis-3 criteria (either in the original publication or after contacting corresponding authors), were qualified as zero uncertainty; articles reporting mean/ median SOFA score with respective standard deviation (SD)/ interquartile range (IQR) were qualified as low uncertainty, whereas articles allowing extraction of SOFA score $\geq 2$, based at least on one reported specific organ dysfunction were characterized as intermediate and articles where only severity of disease (e.g. need for mechanical ventilation, need for ICU, or presence of "critical illness") could be used as a proxy for sepsis were considered of high uncertainty. The following assumptions were made: mechanical ventilation and non-invasive mechanical ventilation were considered as a $\mathrm{PaO} 2$ : $\mathrm{FiO} 2$ ratio $<300$, and thus as SOFA score of $\geq 2$. Among articles allowing extraction of SOFA score $\geq 2$ for different organ dysfunctions, a conservative approach for calculating the primary outcome was followed and only one organ was considered (the one with the maximum number of 
affected patients within the cohort). Among articles reporting medians (interquartile range), outcomes were calculated as the minimum $n$ observed. In order to avoid including patients with sepsis due to secondary bacterial infections, corresponding authors of publications reporting "sepsis" among outcomes were contacted for clarification.

\section{Endpoints and outcome measures}

The primary endpoint was the prevalence of sepsis among COVID-19 patients. The outcome measure was the proportion of patients with COVID-19 who fulfill the criteria for sepsis with $95 \%$ confidence intervals (CI). Secondary outcomes included: i) the prevalence of new onset infection-related organ dysfunction; ii) the prevalence of organ support and/or replacement (invasive and non-invasive mechanical ventilation, including high-flow nasal cannula, vasopressors, ECMO, liver and renal replacement therapy); iii) the prevalence of ICU admission; iv) the mortality of COVID-19 patients with and without sepsis; and iv) the presence of alterations of inflammation and coagulation markers. The outcome measure for each secondary outcome was the respective proportion of patients with COVID-19 and $95 \% \mathrm{Cl}$.

\section{Sensitivity analysis}

Separate sensitivity analyses were planned per adult vs pediatric populations and per ICU vs non-ICU populations. Also, sensitivity analysis was performed among studies with low and zero vs high uncertainty regarding the primary outcome. An additional sensitivity analysis was planned for studies reporting patients without selection criteria (all-comers) vs those reporting on specific selected groups. Articles reporting on mixed cohorts (both ICU and non-ICU or adult and pediatric) were 
included in the primary analysis as a whole and in the sensitivity analyses with the subgroup concerned in the denominator.

\section{Statistical analysis}

All eligible studies were included in a narrative synthesis and after reviewing all included studies. Meta-analysis was performed using the R software v. 4.0.2 (14) after installing the packages "meta" (15), "metaphor" (16) and "dmetar" (17). Some results were validated in the Review Manager (RevMan, The Cochrane Collaboration) Version 5.4. In all cases the random effects model was employed. For each analysis, the corresponding forest plot was produced, while publication bias was assessed with the Egger's test via funnel plot asymmetry (18).

\section{Role of the funding source}

There was no funding source for this study.

\section{RESULTS}

The literature search yielded 1,903 articles; of these, after removal of duplicates and of articles with irrelevant title, 238 were screened full-text by the reviewers (E. Ky and E. Ka). After removal of articles fulfilling exclusion criteria, 104 articles including a total of 157,063 patients were finally analyzed (Figure 1). Data on primary endpoint were provided in 92 studies including a total of 147,881 patients. Of the 104 included studies, mainly observational retrospective, 42 were reporting results from China (19-60), 19 from the U.S.A (61-79), 5 from the U.K (80-84), 24 across Europe, mainly Italy, Spain, France and the Netherlands (85-109), 10 from other countries (110-119) and 3 were international (120-122). All studies reported 
data on hospitalized patients due to COVID-19 and 35 of them included data for ICU $(20,25,33,36,37,41,44,45,48,52,53,56,58,66,72,73,81-84,86-89,95,96$, 98, 101, 103, 106, 107, 109, 111, 119). Eight studies were pediatric $(59,60,78,79$, $83,84,118,119)$. The majority of articles included patients without any selection criteria (all-comers), whereas forty-five focused on specific subgroups, such as critically ill, cancer or rheumatologic patients, patients on mechanical ventilation etc. No studies were found that reported sepsis based on Sepsis-3 or Sepsis-1/2 criteria per se in the original publication; zero uncertainty was only achieved when corresponding authors contacted, provided the exact number of patients presenting sepsis based on sepsis-3. Characteristics of the included studies are presented in eTable 1 and quality assessment with MINORS of each in eTable 2.

\section{Primary endpoint}

The pooled estimate for the prevalence of sepsis among COVID-19 patients was $39.9 \%\left(95 \% \mathrm{Cl}, 35.9-44.1 ; \mathrm{I}^{2}, 99 \%\right)$ as assessed from 92 studies reporting data on the primary endpoint (eFigure 1). Due to the high heterogeneity observed, the results of sensitivity analyses are presented in Figure 2. In sensitivity analysis focusing on ICU versus non-ICU cohorts, among forty studies of a total of 112,796 patients, the pooled estimate for sepsis prevalence was $25.1 \%\left(95 \% \mathrm{Cl}, 21.8-28.9 ; \mathrm{I}^{2}\right.$ $99 \%$ ) in the general ward (Figure $2 \mathrm{~A}$ ). The respective estimate for adult patients in the ICU was $83.8 \%\left(95 \% \mathrm{Cl}, 78.1-88.2 ; \mathrm{I}^{2}\right.$ 91\%) among 31 articles assessed including 3,528 patients ( $p<0.0001$ ) (Figure $2 B$ ). In sensitivity analysis among pediatric cohorts, sepsis in children hospitalized outside the ICU was as high as $7.8 \%$ (95\% Cl, 0.4-64.9; $\left.\mathrm{I}^{2}, 97 \%\right)$ among 3 studies assessed (Figure $\left.2 \mathrm{C}\right)$, whereas only one study provided data for ICU (all 78 children septic) (84). Respective funnel plots of 
the above analyses are provided in eFigure 2. Sensitivity analyses including only articles with zero uncertainty (4 studies outside the ICU and 3 in the ICU, eFigure 3) and high uncertainty (13 studies outside the ICU and 3 in the ICU, eFigure 4) provided similar pooled estimates of sepsis prevalence outside of the ICU, which were $17.1 \%\left(95 \% \mathrm{Cl}, 6.4-38.4 ; \mathrm{I}^{2}, 97 \%\right)$ in zero uncertainty analysis and $21.9 \%$ $\left(95 \% \mathrm{Cl}, 16.9-27.9 ; \mathrm{I}^{2}, 93 \%\right)$ in high uncertainty analysis. However, the pooled estimate in the ICU was $95.7 \%\left(95 \% \mathrm{Cl}, 75.5-99.4 ; \mathrm{I}^{2}, 65 \%\right)$ and $34.7 \%(95 \% \mathrm{Cl}, 9.9$ $\left.72.0, \mathrm{I}^{2}, 92 \%\right)$ in zero and high uncertainty analysis respectively $(\mathrm{p}<0.0001)$, reducing the heterogeneity and yielding a significant difference between the two groups.

\section{Secondary endpoints}

We described the prevalence of different organ dysfunctions, of admission in the ICU, and of organ support and/or replacement among the 104 studies included. A synthesis of the estimates of prevalence of organ dysfunctions in adults is presented in eTables 3 and 4; similar pediatric data are presented in eTable 5. Acute Respiratory Distress Syndrome (ARDS) was the most common organ dysfunction both in non-ICU and ICU patients. ARDS prevalence in non-ICU wards was $27.6 \%$ $\left(95 \% \mathrm{Cl}, 21.6-34.5 ; \mathrm{I}^{2}, 99 \%\right)$ whereas in ICU reached $88.3 \%\left(95 \% \mathrm{Cl}, 79.7-93.5 ; \mathrm{I}^{2}\right.$, $97 \% ; p<0.0001)$. Shock was the second most common dysfunction in ICU patients, followed by renal and liver dysfunction (Table 1, eFigure 5). Coagulopathy was the second most common organ dysfunction among non-ICU patients. Prevalence of all organ dysfunctions was much higher in ICU than non-ICU patients except for coagulopathy and central nervous system dysfunction; the prevalence of these dysfunctions interestingly remained similar. 
Among adult patients hospitalized in the general ward, $16.9 \%(95 \% \mathrm{Cl}, 14.0$ $20.1 ; 1^{2}, 96 \%$ ) required ICU admission (Figure 3). As expected, need for organ replacement was more likely among ICU than non-ICU patients (Table 2). Pooled estimates of patients in the ICU requiring mechanical ventilation (eFigure 6A), renal replacement (eFigure 6B), and ECMO (eFigure 6C) were 57.3\% (95\% Cl, 44.1-69.5; $\left.\mathrm{I}^{2}, 97 \%\right), 14.1 \%\left(95 \% \mathrm{Cl}, 9.5-20.3 ; \mathrm{I}^{2}, 91 \%\right)$, and $6.7 \%\left(95 \% \mathrm{Cl}, 3.5-12.6 ; \mathrm{I}^{2}, 93 \%\right)$, respectively.

Mortality could not be assessed separately for patients with and without sepsis. Nevertheless, Yang X. et al, reported that median SOFA of survivors was 4 (interquartile range [IQR], 3-4) compared to 6 (IQR, 4-8) for non-survivors, showing an indirect effect of sepsis severity on final outcome (20). Similar results were reported by others $(33,73)$. Zou $\mathrm{X}$ et al, estimated the hazard ratio (HR) of SOFA score for death $1.40(95 \% \mathrm{Cl}, 1.28-1.54)(37)$.

Finally, selected literature was searched for the presence of alterations in inflammation and coagulation markers. Reported markers are summarized in eTables 6 and 7. Lymphopenia was reported in most studies, as well as elevation of acute phase proteins such as ferritin and C-reactive protein (CRP). Ferritin was frequently ( 7 of 14 studies) elevated with cocentrations higher than $1,000 \mathrm{ng} / \mathrm{mL}$, whereas the elevation of CRP was more inconsistent. Procalcitonin remained low in almost all cases, as expected in viral infections. The coagulation pathway was also in many studies affected with elevation of fibrinogen and d-dimers, whereas prothrombin time (PT) and activated partial thromboplastin time (aPTT) interestingly hardly ever deviated above the upper normal limit.

\section{DISCUSSION}


In this systematic review and meta-analysis, we showed that sepsis, based on Sepsis-3 criteria, is present in a considerable proportion of hospitalized patients with COVID-19. Sepsis affects $25 \%$ of adult COVID-19 patients outside the ICU and up to $83.8 \%$ of those admitted in the ICU. In hospitalized children with COVID-19, sepsis is as high as $7.8 \%$. ARDS is the most common organ dysfunction both in ICU and nonICU patients.

Sepsis in COVID-19 is more frequently implied, rather than reported. Already in the first published reports, COVID-19 was identified as a potential cause of multiple organ failure leading to death. Chen et al, reported confusion in $9 \%$, acute kidney injury in $3 \%$, shock in $4 \%$, and liver dysfunction in about $50 \%$ of patients.

Interestingly, bacterial or fungal coinfection was present only in $1 \%$ and $4 \%$ of cases, respectively, suggesting that SARS-CoV-2 was the main cause of infection-related organ dysfunction, although the incidence of opportunistic infections is likely to rise after the widespread introduction of dexamethasone as treatment (4). Similar results were reported by other studies (5). Viral sepsis has also been associated with influenza A (ARDS present in $72.6 \%$ and shock in $32.7 \%$ of critically ill patients with $\mathrm{H} 1 \mathrm{~N} 1$ and $\mathrm{H} 3 \mathrm{~N} 2$ ), but variably attributed to secondary bacterial infections, which is not the case in SARS-CoV-2 $(123,124)$.

Pediatric data were obviously sparse. Children are less affected by the virus, estimated as $1-5 \%$ of total cases and if ill, they present with milder symptoms. Although prevalence of sepsis was lower than in adults, it was still higher than expected based on initial reports (125).

Key mechanisms that may have a role in the pathophysiology of multi-organ injury secondary to infection with SARS-CoV-2 include direct viral toxicity, endothelial cell damage and thrombo-inflammation, dysregulation of the immune response, and 
dysregulation of the renin-angiotensin-aldosterone system (RAAS) (126). Some of these mechanisms may be unique to COVID-19 such as that multiple-organ injury may occur at least in part due to direct viral tissue damage $(127,128)$. The host response with activation of the adaptive and innate immune system and the resulting systemic release of cytokines and activation of the complement system, are common features of both bacterial and viral sepsis $(126,129,130)$.

Severe COVID-19 has been shown to display a similar cytokine profile in terms of baseline levels of interleukin (IL)-1 $\beta$, IL-1RA, IL-6, IL-8, IL-18, and TNF- $\alpha$, as ARDS of other etiology and bacterial sepsis, although the absolute circulating concentrations tend to be somewhat lower (131). The presence of macrophage activation-like syndrome, an extreme phenotype of bacterial sepsis, characterized by hyperferritinemia, coagulation disorders, liver dysfunction and high mortality, is also present in severe COVID-19. $(8,132,133)$. Meanwhile, it has been demonstrated that the host response is characterized by a dysregulated activation of the innate immune system coupled with tissue damage by neutrophils and monocytes driving the interplay of inflammation and coagulation $(129,130)$. Altogether, these observations suggest that death from COVID-19 to significant degree is a consequence of immune-mediated organ damage, rather than a result of the infection itself $(3,8)$.

Following the paradigm of bacterial sepsis and since no specific antiviral treatment is available for COVID-19, immune targeting therapies have been tested through several clinical trials; corticosteroids, IL-1 and IL-6 blockade and inhibition of factors of the complement system have been administered to patients with organ dysfunctions with promising results (134-139). Similarities between sepsis and COVID-19 have been early recognized by sepsis experts, issuing a written guide for appropriate management of COVID-19 (140). 
To the best of our knowledge, this is the first study to address in a systematic way the presence of sepsis, according to Sepsis-3 criteria, among hospitalized patients with COVID-19, and the first to provide pooled estimates of specific organ dysfunctions. Of course, the conservative approach used in SOFA score extraction (i.e. median or mean SOFA of included cohorts) may have resulted in an underestimation of sepsis prevalence. Sensitivity analyses focusing on low uncertainty data provided similar prevalence, reducing this potential bias. High heterogeneity was observed in almost all results, which could not be eliminated by sensitivity analyses. This can be explained by the heterogeneity in reporting and definitions of organ dysfunctions in the various studies, a shift in criteria for hospitalization since the beginning of the pandemic (e.g. mild cases tend to receive home care). Above all, it is likely that COVID-19-associated sepsis, similar to bacterial sepsis and ARDS, is a heterogenous disease and every effort should be made to identify patients at high risk for those complications.

In conclusion, a considerable proportion of patients with COVID-19 present viral sepsis. Lessons learned from bacterial sepsis may apply, in terms of early recognition (by means of SOFA and/or qSOFA score) and potential benefit from immune regulating strategies.

\section{Contributors}

E.Ky. performed literature search and study selection, participated in data analysis and drafted the manuscript. E.Ka. performed literature search and study selection and participated in data analysis and drafting of the manuscript. M.K. performed data analysis. C.F.S., M.G.N. and K.R. conceptualized the study and revised the manuscript for important intellectual content. E.J.G.B. conceptualized the study, 
participated in literature search, study selection and drafting the manuscript. All authors gave approval for the version to be published.

\section{Declaration of interests}

E Ka is funded by the Horizon 2020 Marie Skłodowska-Curie Grant European Sepsis Academy (grant 676129 paid to the University of Athens).

E.J.G.B. has received honoraria from AbbVie USA, Abbott $\mathrm{CH}$, Biotest Germany, Brahms GmbH, InflaRx GmbH, MSD Greece, XBiotech Inc. and Angelini Italy; independent educational grants from AbbVie, Abbott $\mathrm{CH}$, Astellas Pharma Europe, AxisShield, bioMérieux Inc, InflaRx GmbH, the Medicines Company and XBiotech Inc.; and funding from the FrameWork 7 program HemoSpec (granted to the National and Kapodistrian University of Athens), the Horizon2020 Marie-Curie Project European Sepsis Academy (granted to the National and Kapodistrian University of Athens), and the Horizon 2020 European Grant ImmunoSep (granted to the Hellenic Institute for the Study of Sepsis).

M.G.N. is supported by an ERC Advanced Grant (\#833247) and a Spinoza grant of the Netherlands Organization for Scientific Research. He has also received independent educational grants from TTxD, GSK and ViiV HealthCare.

K.R. was unpaid President of the Global Sepsis Alliance until November 2020 and is shareholder with less of $0.1 \%$ of InflaRx NV a Jena /Germany based Biotech Company that evaluates an immune-modulatory approach for the adjunctive treatment of COVID-19.

The other authors do not have any competing interest to declare.

\section{Acknowledgements}


medRxiv preprint doi: https://doi.org/10.1101/2020.12.02.20242354; this version posted December 4, 2020. The copyright holder for this preprint (which was not certified by peer review) is the author/funder, who has granted medRxiv a license to display the preprint in perpetuity. All rights reserved. No reuse allowed without permission.

There was no funding source for this study.

The authors would like to thank following researchers/scientists for providing clinical data for this study: Dr. Marco Metra, Dr. Laura Lupi, Dr. Calum Semple, Dr. Annemarie Docherty, Dr. Stephen Knight, Dr. Donald E Griesdale, Dr. Nick Fergusson, Dr. Matteo Pagnesi, Dr. Furkan Korkmaz, Dr. Matthijs Kox, Dr. Giuliano Bolondi, Dr. Margaux Lafaurie and Dr. Guillaume Moulis. 
medRxiv preprint doi: https://doi.org/10.1101/2020.12.02.20242354; this version posted December 4, 2020. The copyright holder for this preprint (which was not certified by peer review) is the author/funder, who has granted medRxiv a license to display the preprint in perpetuity.

All rights reserved. No reuse allowed without permission.

\section{References}

1. World Health Organization. Coronavirus disease (COVID-19) pandemic. Available from: https://www.who.int/emergencies/diseases/novel-coronavirus-

\section{9?gclid=Cj0KCQiAhs79BRD0ARIsAC6XpaXhxHeN64r7-}

j5rvv0ZDtNGxNkA0e2EWCAUr8QWWj-qi PPrXOljroaAjXBEALw wcB. Last

access: November 17, 2020.

2. Grasselli G, Greco M, Zanella A, et al. Risk Factors Associated With Mortality Among Patients With COVID-19 in Intensive Care Units in Lombardy, Italy. JAMA Intern Med 2020; 180: 1345-1355.

3. Zhou F, Yu T, Du R, et al. Clinical course and risk factors for mortality of adult inpatients with COVID-19 in Wuhan, China: a retrospective cohort study. Lancet 2020; 395: 1054-1062.

4. Chen N, Zhou M, Dong X, et al. Epidemiological and clinical characteristics of 99 cases of 2019 novel coronavirus pneumonia in Wuhan, China: a descriptive study. Lancet 2020; 395: 507-513.

5. Wang D, Hu B, Hu C, et al. Clinical Characteristics of 138 Hospitalized Patients With 2019 Novel Coronavirus-Infected Pneumonia in Wuhan, China. JAMA 2020; 323: 1061-1069.

6. Singer M, Deutschman CS, Seymour CW, et al. The Third International Consensus Definitions for Sepsis and Septic Shock (Sepsis-3). JAMA 2016; 315: 801-10.

7. World Health Organization. Improving the prevention, diagnosis and clinical management of sepsis. Available from:

https://apps. who.int/gb/ebwha/pdf files/WHA70/A70 13-en.pdf. Last access November 29, 2020. 
8. Giamarellos-Bourboulis EJ, Netea MG, Rovina N, et al. Complex Immune Dysregulation in COVID-19 Patients with Severe Respiratory Failure. Cell Host Microbe 2020; 27: 992-1000.e3.

9. Li H, Liu L, Zhang D, et al. SARS-CoV-2 and viral sepsis: observations and hypotheses. Lancet 2020; 395: 1517-1520.

10. Moher D, Shamseer L, Clarke M, et al. Preferred reporting items for systematic review and meta-analysis protocols (PRISMA-P) 2015 statement. Syst Rev 2015;

\section{4: 1.}

11. Bone RC, Balk RA, Cerra FB, et al. Definitions for sepsis and organ failure and guidelines for the use of innovative therapies in sepsis. The ACCP/SCCM Consensus Conference Committee. American College of Chest Physicians/Society of Critical Care Medicine. Chest 1992; 101: 1644-55.

12. Levy MM, Fink MP, Marshall JC, et al. 2001 SCCM/ESICM/ACCP/ATS/SIS International Sepsis Definitions Conference. Intensive Care Med 2003; 29: 530-8.

13. Slim K, Nini E, Forestier D, Kwiatkowski F, Panis Y, Chipponi J. Methodological index for non-randomized studies (minors): development and validation of a new instrument. ANZ J Surg 2003; 73: 712-6.

14. R Core Team (2013). R: A language and environment for statistical computing. $R$ Foundation for Statistical Computing, Vienna, Austria. Accessed by: http://www.Rproject.org/.

15. Balduzzi S, Rücker G, Schwarzer G. How to perform a meta-analysis with R: a practical tutorial. Evidence-Based Mental Health 2019; 153-60.

16. Viechtbauer W. Conducting meta-analyses in $\mathrm{R}$ with the metafor package. Journal of Statistical Software, 2010; 36:1-48. 
17. Harrer M, Cuijpers P, FurukawaT, Ebert DD. dmetar: Companion R Package For The Guide 'Doing Meta-Analysis in R'. R package version 0.0.9000. Accesed by: http://dmetar.protectlab.org/.

18. Egger M, Davey Smith G, Schneider M, Minder C. Bias in meta-analysis detected by a simple, graphical test. BMJ 1997; 315:629-34.

19. Xu XW, Wu XX, Jiang XG, et al. Clinical findings in a group of patients infected with the 2019 novel coronavirus (SARS-Cov-2) outside of Wuhan, China: retrospective case series. BMJ 2020; 368:m606.

20. Yang $\mathrm{X}, \mathrm{Yu} Y, \mathrm{Xu}$ J, et al. Clinical course and outcomes of critically ill patients with SARS-CoV-2 pneumonia in Wuhan, China: a single-centered, retrospective, observational study. Lancet Respir Med 2020; 8: 475-81.

21. Du Y, Tu L, Zhu P, et al. Clinical Features of 85 Fatal Cases of COVID-19 from Wuhan. A Retrospective Observational Study. Am J Respir Crit Care Med 2020; 201: 1372-9.

22. Dai M, Liu D, Liu M, et al. Patients with Cancer Appear More Vulnerable to SARSCoV-2: A Multicenter Study during the COVID-19 Outbreak. Cancer Discov 2020; 10: 783-91.

23. Feng Y, Ling Y, Bai T, et al. COVID-19 with Different Severities: A Multicenter Study of Clinical Features. Am J Respir Crit Care Med 2020; 201: 1380-8.

24. Yan $Y$, Yang $Y$, Wang $F$, et al. Clinical characteristics and outcomes of patients with severe covid-19 with diabetes. BMJ Open Diabetes Res Care 2020; 8: e001343.

25. Tang X, Du RH, Wang R, et al. Comparison of Hospitalized Patients With ARDS Caused by COVID-19 and H1N1. Chest 2020; 158: 195-205. 
26. Du RH, Liu LM, Yin W, et al. Hospitalization and Critical Care of 109 Decedents with COVID-19 Pneumonia in Wuhan, China. Ann Am Thorac Soc 2020; 17: 83946.

27. Zhang P, Zhu L, Cai J, et al. Association of Inpatient Use of AngiotensinConverting Enzyme Inhibitors and Angiotensin II Receptor Blockers With Mortality Among Patients With Hypertension Hospitalized With COVID-19. Circ Res 2020; 126: $1671-81$.

28. Yang X, Yang Q, Wang Y, et al. Thrombocytopenia and its association with mortality in patients with COVID-19. J Thromb Haemost 2020; 18: 1469-72.

29. Huang R, Zhu L, Xue L, et al. Clinical findings of patients with coronavirus disease 2019 in Jiangsu province, China: A retrospective, multi-center study. PLoS Negl Trop Dis 2020; 14: e0008280.

30. Cai SH, Liao W, Chen SW, Liu LL, Liu SY, Zheng ZD. Association between obesity and clinical prognosis in patients infected with SARS-CoV-2. Infect Dis Poverty 2020; 9: 80.

31. Li K, Chen D, Chen S, et al. Predictors of fatality including radiographic findings in adults with COVID-19. Respir Res 2020; 21: 146.

32. Wang K, Zhang Z, Yu M, Tao Y, Xie M. 15-day mortality and associated risk factors for hospitalized patients with COVID-19 in Wuhan, China: an ambispective observational cohort study. Intensive Care Med 2020; 46: 1472-4.

33. Xu J, Yang X, Yang L, et al. Clinical course and predictors of 60-day mortality in 239 critically ill patients with COVID-19: a multicenter retrospective study from Wuhan, China. Crit Care 2020; 24: 394. 
34. Han $\mathrm{Y}$, Zhang $\mathrm{H}$, Mu S, et al. Lactate dehydrogenase, an independent risk factor of severe COVID-19 patients: a retrospective and observational study. Aging (Albany NY) 2020; 12: 11245-58.

35. Cui X, Yu X, Wu X, et al. Acute Kidney Injury in Patients with the Coronavirus Disease 2019: A Multicenter Study. Kidney Blood Press Res 2020; 45: 612-22.

36. Huang M, Yang Y, Shang F, et al. Clinical Characteristics and Predictors of Disease Progression in Severe Patients with COVID-19 Infection in Jiangsu Province, China: A Descriptive Study. Am J Med Sci 2020; 360: 120-8.

37.Zou X, Li S, Fang M, et al. Acute Physiology and Chronic Health Evaluation II Score as a Predictor of Hospital Mortality in Patients of Coronavirus Disease 2019. Crit Care Med 2020; 48: e657-e665.

38. Wu J, Liu J, Zhao X, et al. Clinical Characteristics of Imported Cases of Coronavirus Disease 2019 (COVID-19) in Jiangsu Province: A Multicenter Descriptive Study. Clin Infect Dis 2020; 71: 706-12.

39. Song J, Hu W, Yu Y, et al. A Comparison of Clinical Characteristics and Outcomes in Elderly and Younger Patients with COVID-19. Med Sci Monit 2020; 26: e925047.

40. Zhang J, Kong W, Xia P, et al. Impaired Fasting Glucose and Diabetes Are Related to Higher Risks of Complications and Mortality Among Patients With Coronavirus Disease 2019. Front Endocrinol (Lausanne) 2020; 11: 525.

41. Huang C, Wang Y, Li X, et al. Clinical features of patients infected with 2019 novel coronavirus in Wuhan, China. Lancet 2020; 395: 497-506.

42. Zhao M, Wang M, Zhang J, et al. Comparison of clinical characteristics and outcomes of patients with coronavirus disease 2019 at different ages. Aging (Albany NY) 2020; 12: 10070-86. 
43. Lu L, Xiong W, Liu D, et al. New onset acute symptomatic seizure and risk factors in coronavirus disease 2019: A retrospective multicenter study. Epilepsia 2020; 61: e49-e53.

44. Cao Y, Wei J, Zou L, et al. Ruxolitinib in treatment of severe coronavirus disease 2019 (COVID-19): A multicenter, single-blind, randomized controlled trial. $J$ Allergy Clin Immunol 2020; 146: 137-146.e3.

45. Yu Y, Xu D, Fu S, et al. Patients with COVID-19 in 19 ICUs in Wuhan, China: a cross-sectional study. Crit Care 2020; 24: 219.

46. Xu PP, Tian $\mathrm{RH}$, Luo S, et al. Risk factors for adverse clinical outcomes with COVID-19 in China: a multicenter, retrospective, observational study. Theranostics 2020; 10: 6372-83.

47. Zhang Y, Li H, Zhang J, et al. The clinical characteristics and outcomes of patients with diabetes and secondary hyperglycaemia with coronavirus disease 2019: A single-centre, retrospective, observational study in Wuhan. Diabetes Obes Metab 2020; 22: 1443-54.

48. Zheng Y, Sun LJ, Xu M, et al. Clinical characteristics of 34 COVID-19 patients admitted to intensive care unit in Hangzhou, China. J Zhejiang Univ Sci B 2020; 21: $378-87$.

49. Xie Y, You Q, Wu C, et al. Impact of Cardiovascular Disease on Clinical Characteristics and Outcomes of Coronavirus Disease 2019 (COVID-19). Circ J 2020; 84: 1277-83.

50. Wan Y, Li J, Shen L, et al. Enteric involvement in hospitalised patients with COVID-19 outside Wuhan. Lancet Gastroenterol Hepatol 2020; 5: 534-5. 
51. Huang S, Wang J, Liu F, et al. COVID-19 patients with hypertension have more severe disease: a multicenter retrospective observational study. Hypertens Res 2020; 43: 824-31.

52. Chen Y, Zhang K, Zhu G, et al. Clinical characteristics and treatment of critically ill patients with COVID-19 in Hebei. Ann Palliat Med 2020; 9: 2118-30.

53. Cao J, Zheng Y, Luo Z, et al. Myocardial injury and COVID-19: Serum hs-cTnl level in risk stratification and the prediction of 30-day fatality in COVID-19 patients with no prior cardiovascular disease. Theranostics 2020; 10: 9663-73.

54. Guo T, Fan Y, Chen M, et al. Cardiovascular Implications of Fatal Outcomes of Patients With Coronavirus Disease 2019 (COVID-19). JAMA Cardiol 2020; 5: 811-8.

55. Lei F, Liu YM, Zhou F, et al. Longitudinal Association Between Markers of Liver Injury and Mortality in COVID-19 in China. Hepatology 2020; 72: 389-98.

56. Yang X, Cai S, Luo Y, et al. Extracorporeal Membrane Oxygenation for Coronavirus Disease 2019-Induced Acute Respiratory Distress Syndrome: A Multicenter Descriptive Study. Crit Care Med 2020; 48:1 289-95.

57. Guo T, Shen Q, Guo W, et al. Clinical Characteristics of Elderly Patients with COVID-19 in Hunan Province, China: A Multicenter, Retrospective Study. Gerontology 2020; 66: 467-75.

58. Li L, Zhang W, Hu Y, et al. Effect of Convalescent Plasma Therapy on Time to Clinical Improvement in Patients With Severe and Life-threatening COVID-19: A Randomized Clinical Trial. JAMA 2020; 324: 460-70.

59. Li H, Chen K, Liu M, Xu H, Xu Q. The profile of peripheral blood lymphocyte subsets and serum cytokines in children with 2019 novel coronavirus pneumonia. J Infect 2020; 81: 115-20. 
60.Zhang C, Gu J, Chen Q, et al. Clinical and epidemiological characteristics of pediatric SARS-CoV-2 infections in China: A multicenter case series. PLoS Med 2020; 17: e1003130.

61. Hirsch JS, Ng JH, Ross DW, et al. Acute kidney injury in patients hospitalized with COVID-19. Kidney Int 2020; 98: 209-18.

62. Arshad S, Kilgore P, Chaudhry ZS, et al. Treatment with hydroxychloroquine, azithromycin, and combination in patients hospitalized with COVID-19. Int J Infect Dis 2020; 97: 396-403.

63. Ferguson J, Rosser JI, Quintero O, et al. Characteristics and Outcomes of Coronavirus Disease Patients under Nonsurge Conditions, Northern California, USA, March-April 2020. Emerg Infect Dis 2020; 26: 1679-85.

64. Ebinger JE, Achamallah N, Ji H, et al. Pre-existing traits associated with Covid-19 illness severity. PLoS One 2020; 15: e0236240.

65. Satlin MJ, Goyal P, Magleby R, et al. Safety, tolerability, and clinical outcomes of hydroxychloroquine for hospitalized patients with coronavirus 2019 disease. PLoS One 2020; 15: e0236778.

66. Cummings MJ, Baldwin MR, Abrams D, et al. Epidemiology, clinical course, and outcomes of critically ill adults with COVID-19 in New York City: a prospective cohort study. Lancet 2020; 395: 1763-70.

67. Thomas T, Stefanoni D, Reisz JA, et al. COVID-19 infection alters kynurenine and fatty acid metabolism, correlating with IL-6 levels and renal status. JCI Insight 2020; 5: 140327.

68. Hur K, Price CPE, Gray EL, et al. Factors Associated With Intubation and Prolonged Intubation in Hospitalized Patients With COVID-19. Otolaryngol Head Neck Surg 2020; 163: 170-8. 
69. Turcotte JJ, Meisenberg BR, MacDonald JH, et al. Risk factors for severe illness in hospitalized Covid-19 patients at a regional hospital. PLoS One 2020; 15: e0237558.

70. Ip A, Berry DA, Hansen E, et al. Hydroxychloroquine and tocilizumab therapy in COVID-19 patients-An observational study. PLoS One 2020; 15: e0237693.

71. Joyner MJ, Bruno KA, Klassen SA, et al. Safety Update: COVID-19 Convalescent Plasma in 20,000 Hospitalized Patients. Mayo Clin Proc 2020; 95: 1888-97.

72. Krause M, Douin DJ, Tran TT, Fernandez-Bustamante A, Aftab M, Bartels K. Association between procalcitonin levels and duration of mechanical ventilation in COVID-19 patients. PLoS One 2020; 15: e0239174.

73. Auld SC, Caridi-Scheible M, Blum JM, et al. ICU and Ventilator Mortality Among Critically III Adults With Coronavirus Disease 2019. Crit Care Med 2020; 48: e799e804.

74. D'Silva KM, Serling-Boyd N, Wallwork R, et al. Clinical characteristics and outcomes of patients with coronavirus disease 2019 (COVID-19) and rheumatic disease: a comparative cohort study from a US 'hot spot'. Ann Rheum Dis 2020; 79: 1156-62.

75. Maatman TK, Jalali F, Feizpour C, et al. Routine Venous Thromboembolism Prophylaxis May Be Inadequate in the Hypercoagulable State of Severe Coronavirus Disease 2019. Crit Care Med 2020; 48: e783-90.

76. Imam Z, Odish F, Gill I, et al. Older age and comorbidity are independent mortality predictors in a large cohort of 1305 COVID-19 patients in Michigan, United States. J Intern Med 2020; 288: 469-76.

77. Fisher M, Neugarten J, Bellin E, et al. AKI in Hospitalized Patients with and without COVID-19: A Comparison Study. J Am Soc Nephrol 2020; 31: 2145-57. 
78. Feldstein LR, Rose EB, Horwitz SM, et al. Multisystem Inflammatory Syndrome in U.S. Children and Adolescents. N Engl J Med 2020; 383: 334-46.

79. Kaushik S, Aydin SI, Derespina KR, et al. Multisystem Inflammatory Syndrome in Children Associated with Severe Acute Respiratory Syndrome Coronavirus 2 Infection (MIS-C): A Multi-institutional Study from New York City. J Pediatr 2020; 224: $24-9$.

80. Docherty AB, Harrison EM, Green CA, et al. Features of $20 \square 133$ UK patients in hospital with covid-19 using the ISARIC WHO Clinical Characterisation Protocol: prospective observational cohort study. BMJ 2020; 369: m1985.

81. Shah A, Donovan K, McHugh A, et al. Thrombotic and haemorrhagic complications in critically ill patients with COVID-19: a multicentre observational study. Crit Care 2020; 24: 561.

82. Patel BV, Arachchillage DJ, Ridge CA, et al. Pulmonary Angiopathy in Severe COVID-19: Physiologic, Imaging, and Hematologic Observations. Am J Respir Crit Care Med 2020; 202: 690-9.

83. Swann OV, Holden KA, Turtle L, et al. Clinical characteristics of children and young people admitted to hospital with covid-19 in United Kingdom: prospective multicentre observational cohort study. BMJ 2020; 370: m3249.

84. Davies P, Evans C, Kanthimathinathan HK, et al. Intensive care admissions of children with paediatric inflammatory multisystem syndrome temporally associated with SARS-CoV-2 (PIMS-TS) in the UK: a multicentre observational study. Lancet Child Adolesc Health 2020; 4: 669-77.

85. Inciardi RM, Adamo M, Lupi L, et al. Characteristics and outcomes of patients hospitalized for COVID-19 and cardiac disease in Northern Italy. Eur Heart J 2020; 41: 1821-9. 
86. Antinori S, Cossu MV, Ridolfo AL, et al. Compassionate remdesivir treatment of severe Covid-19 pneumonia in intensive care unit (ICU) and Non-ICU patients: Clinical outcome and differences in post-treatment hospitalisation status.

Pharmacol Res 2020; 158: 104899.

87. Kox M, Waalders NJB, Kooistra EJ, Gerretsen J, Pickkers P. Cytokine Levels in Critically III Patients With COVID-19 and Other Conditions. JAMA 2020; 324: 1565-7.

88. Bolondi G, Russo E, Gamberini E, et al. Iron metabolism and lymphocyte characterisation during Covid-19 infection in ICU patients: an observational cohort study. World J Emerg Surg 2020; 15: 41.

89. Middeldorp S, Coppens M, van Haaps TF, et al. Incidence of venous thromboembolism in hospitalized patients with COVID-19. J Thromb Haemost 2020; 18: 1995-2002.

90. Pagnesi M, Baldetti L, Beneduce A, et al. Pulmonary hypertension and right ventricular involvement in hospitalised patients with COVID-19. Heart 2020; 106: 1324-31.

91. Vena A, Giacobbe DR, Di Biagio A, et al. Clinical characteristics, management and in-hospital mortality of patients with COVID-19 In Genoa, Italy. Clin Microbiol Infect 2020; S1198-743X(20)30484-5.

92. Demelo-Rodríguez P, Cervilla-Muñoz E, Ordieres-Ortega L, et al. Incidence of asymptomatic deep vein thrombosis in patients with COVID-19 pneumonia and elevated D-dimer levels. Thromb Res 2020; 192: 23-6.

93. Lecronier M, Beurton A, Burrel S, et al. Comparison of hydroxychloroquine, lopinavir/ritonavir, and standard of care in critically ill patients with SARS-CoV-2 pneumonia: an opportunistic retrospective analysis. Crit Care 2020; 24: 418. 
94. Mahévas M, Tran VT, Roumier M, et al. Clinical efficacy of hydroxychloroquine in patients with covid-19 pneumonia who require oxygen: observational comparative study using routine care data. BMJ 2020; 369: m1844.

95. Pavoni V, Gianesello L, Pazzi M, Stera C, Meconi T, Frigieri FC. Evaluation of coagulation function by rotation thromboelastometry in critically ill patients with severe COVID-19 pneumonia. J Thromb Thrombolysis 2020; 50: 281-6.

96. Halvatsiotis P, Kotanidou A, Tzannis K, et al. Demographic and clinical features of critically ill patients with COVID-19 in Greece: The burden of diabetes and obesity. Diabetes Res Clin Pract 2020; 166: 108331.

97. Karagiannidis C, Mostert C, Hentschker C, et al. Case characteristics, resource use, and outcomes of $10 \square 021$ patients with COVID-19 admitted to 920 German hospitals: an observational study. Lancet Respir Med 2020; 8: 853-62.

98. Azoulay E, Fartoukh M, Darmon M, et al. Increased mortality in patients with severe SARS-CoV-2 infection admitted within seven days of disease onset. Intensive Care Med 2020; 46: 1714-22.

99. Mikulska M, Nicolini LA, Signori A, et al. Tocilizumab and steroid treatment in patients with COVID-19 pneumonia. PLoS One 2020; 15: e0237831.

100. Sisó-Almirall A, Kostov B, Mas-Heredia M, et al. Prognostic factors in Spanish COVID-19 patients: A case series from Barcelona. PLoS One 2020; 15: e0237960.

101. Contou D, Pajot O, Cally R, et al. Pulmonary embolism or thrombosis in ARDS COVID-19 patients: A French monocenter retrospective study. PLoS One 2020; 15: e0238413.

102. Catteau L, Dauby N, Montourcy M, et al. Low-dose hydroxychloroquine therapy and mortality in hospitalised patients with COVID-19: a nationwide 
observational study of 8075 participants. Int J Antimicrob Agents 2020; 56:

106144.

103. Grieco DL, Bongiovanni F, Chen L, et al. Respiratory physiology of COVID-19induced respiratory failure compared to ARDS of other etiologies. Crit Care 2020; 24: 529.

104. Poggiali E, Zaino D, Immovilli P, et al. Lactate dehydrogenase and C-reactive protein as predictors of respiratory failure in CoVID-19 patients. Clin Chim Acta 2020; 509: 135-8.

105. Maquet J, Lafaurie M, Sommet A, Moulis G. Thrombocytopenia is independently associated with poor outcome in patients hospitalized for COVID19. Br J Haematol 2020; 190: e276-9.

106. Della-Torre E, Campochiaro C, Cavalli G, et al. Interleukin-6 blockade with sarilumab in severe COVID-19 pneumonia with systemic hyperinflammation: an open-label cohort study. Ann Rheum Dis 2020; 79: 1277-85.

107. Fauvel C, Weizman O, Trimaille A, et al. Pulmonary embolism in COVID-19 patients: a French multicentre cohort study. Eur Heart J 2020; 41: 3058-68.

108. Decrease of Non-Classical and Intermediate Monocyte Subsets in Severe Acute SARS-CoV-2 Infection. Cytometry A 2020; 97: 887-90.

109. Helms J, Tacquard C, Severac F, et al. High risk of thrombosis in patients with severe SARS-CoV-2 infection: a multicenter prospective cohort study. Intensive Care Med 2020; 46: 1089-98.

110. Hung IF, Lung KC, Tso EY, et al. Triple combination of interferon beta-1b, lopinavir-ritonavir, and ribavirin in the treatment of patients admitted to hospital with COVID-19: an open-label, randomised, phase 2 trial. Lancet 2020; 395: 1695-1704. 
111. Mitra AR, Fergusson NA, Lloyd-Smith E, et al. Baseline characteristics and outcomes of patients with COVID-19 admitted to intensive care units in Vancouver, Canada: a case series. CMAJ 2020; 192: E694-E701.

112. Yang K, Sheng $\mathrm{Y}$, Huang $\mathrm{C}$, et al. Clinical characteristics, outcomes, and risk factors for mortality in patients with cancer and COVID-19 in Hubei, China: a multicentre, retrospective, cohort study. Lancet Oncol 2020; 21: 904-13.

113. Jang JG, Hur J, Hong KS, Lee W, Ahn JH. Prognostic Accuracy of the SIRS, qSOFA, and NEWS for Early Detection of Clinical Deterioration in SARS-CoV-2 Infected Patients. J Korean Med Sci 2020; 35: e234.

114. Jang JG, Hur J, Choi EY, Hong KS, Lee W, Ahn JH. Prognostic Factors for Severe Coronavirus Disease 2019 in Daegu, Korea. J Korean Med Sci 2020; 35: e209.

115. Kim MK, Jeon JH, Kim SW, et al. The Clinical Characteristics and Outcomes of Patients with Moderate-to-Severe Coronavirus Disease 2019 Infection and Diabetes in Daegu, South Korea. Diabetes Metab J 2020; 44: 602-13.

116. Davoudi-Monfared E, Rahmani H, Khalili H, et al. A Randomized Clinical Trial of the Efficacy and Safety of Interferon $\beta-1 a$ in Treatment of Severe COVID-19. Antimicrob Agents Chemother 2020; 64: e01061-20.

117. Nadeem A, Hamed F, Saleh K, Abduljawad B, Mallat J. ICU outcomes of COVID-19 critically ill patients: An international comparative study. Anaesth Crit Care Pain Med 2020; 39: 487-9.

118. Korkmaz MF, Türe E, Dorum BA, Kılıç ZB. The Epidemiological and Clinical Characteristics of 81 Children with COVID-19 in a Pandemic Hospital in Turkey: an Observational Cohort Study. J Korean Med Sci 2020; 35: e236. 
119. Kanburoglu MK, Tayman C, Oncel MY, et al. A Multicentered Study on Epidemiologic and Clinical Characteristics of 37 Neonates With Communityacquired COVID-19. Pediatr Infect Dis J 2020; 39: e297-e302.

120. Garassino MC, Whisenant JG, Huang LC, et al. COVID-19 in patients with thoracic malignancies (TERAVOLT): first results of an international, registrybased, cohort study. Lancet Oncol 2020; 21: 914-22.

121. Mato AR, Roeker LE, Lamanna N, et al. Outcomes of COVID-19 in patients with CLL: a multicenter international experience. Blood 2020; 136: 1134-43.

122. Scarfò L, Chatzikonstantinou T, Rigolin GM, et al. COVID-19 severity and mortality in patients with chronic lymphocytic leukemia: a joint study by ERIC, the European Research Initiative on CLL, and CLL Campus. Leukemia 2020; 34: 2354-63.

123. Kumar A, Zarychanski R, Pinto R, et al. JAMA 2009; 302: $1872-9$.

124. Burrell A, Huckson S, Pilcher DV; ANZICS. ICU Admissions for Sepsis or Pneumonia in Australia and New Zealand in 2017. N Engl J Med 2018; 378: 2138-9.

125. Lu X, Zhang L, Du H, et al. SARS-CoV-2 Infection in Children. N Engl J Med 2020; 382: 1663-5.

126. Gupta A, Madhavan MV, Sehgal K, et al. Extrapulmonary manifestations of COVID-19. Nat Med2020; 26: 1017-1032.

127. Guan WJ, Ni ZY, Hu Y, et al. Clinical Characteristics of Coronavirus Disease 2019 in China. N Engl J Med 2020; 382: 1708-20.

128. Puelles VG, Lütgehetmann M, Lindenmeyer MT, et al. Multiorgan and Renal Tropism of SARS-CoV-2. N Engl J Med 2020; 383: 590-2. 
129. Carvelli J, Demaria O, Vély F, et al. Association of COVID-19 inflammation with activation of the C5a-C5aR1 axis. Nature 2020; doi: 10.1038/s41586-0202600-6.

130. Chua RL, Lukassen S, Trump S, et al. COVID-19 severity correlates with airway epithelium-immune cell interactions identified by single-cell analysis. Nat Biotechnol 2020; 38: 970-9.

131. Wilson JG, Simpson LJ, Ferreira AM, et al. Cytokine profile in plasma of severe COVID-19 does not differ from ARDS and sepsis. JCI Insight 2020; 5: e140289.

132. Kyriazopoulou E, Leventogiannis K, Norrby-Teglund A, et al. Macrophage activation-like syndrome: an immunological entity associated with rapid progression to death in sepsis. BMC Med 2017; 15: 172.

133. Swoboda J, Wittschieber D, Sanft J, et al. Bone marrow haemophagocytosis designate severe SARS-CoV-2 infections. Histopathology 2020: doi:

10.1111/his. 14281 .

134. RECOVERY Collaborative Group, Horby P, Lim WS, Emberson JR, et al. Dexamethasone in Hospitalized Patients with Covid-19 - Preliminary Report. $N$ Engl J Med 2020: NEJMoa2021436.

135. Lewis TC, Adhikari S, Tatapudi V, et al. A Propensity-Matched Cohort Study of Tocilizumab in Patients With Coronavirus Disease 2019. Crit Care Explor 2020; 2: e0283.

136. Bozzi G, Mangioni D, Minoia F, et al. Anakinra combined with methylprednisolone in patients with severe COVID-19 pneumonia and hyperinflammation: an observational cohort study. J Allergy Clin Immunol 2020: S0091-6749(20)31621-3. 
137. Dimopoulos G, de Mast Q, Markou N, et al. Cell Host Microbe 2020; 28: 117123.e1.

138. Vlaar APJ, de Bruin S, Busch M, et al. Anti-C5a antibody IFX-1 (vilobelimab) treatment versus best supportive care for patients with severe COVID-19 (PANAMO): an exploratory, open-label, phase 2 randomised controlled trial. Lancet Rheumatol 2020; 2: e764-e773.

139. Annane D, Heming N, Grimaldi-Bensouda L, et al. Eculizumab as an emergency treatment for adult patients with severe COVID-19 in the intensive care unit: A proof-of-concept study. EClinicalMedicine 2020; 28: 100590.

140. Alhazzani W, Møller MH, Arabi YM, et al. Surviving Sepsis Campaign: guidelines on the management of critically ill adults with Coronavirus Disease 2019 (COVID-19). Intensive Care Med 2020; 46: 854-87. 


\section{Figure Legends.}

Figure 1. Study selection.

Figure 2. Forest plot of sepsis prevalence in A) adult patients outside the Intensive Care Unit (ICU); B) adult patients in the ICU; and C) pediatric patients outside the ICU.

Only studies with zero and low uncertainty have been included. All included studies have been published in 2020 .

Abbreviation: $\mathrm{Cl}$, confidence interval.

Figure 3. Forest plot of prevalence of admission in the Intensive Care Unit among adult patients with COVID-19 hospitalized in general wards.

Only studies with zero and low uncertainty have been included. All included studies have been published in 2020 .

Abbreviation: $\mathrm{Cl}$, confidence interval. 
Table 1. Summary of the pooled estimates of prevalence of organ dysfunctions among adult patients hospitalized in the Intensive Care Unit (ICU) and non-ICU wards.

\begin{tabular}{|c|c|c|c|c|c|c|c|c|c|c|c|c|}
\hline \multirow[b]{2}{*}{ Dysfunction } & \multicolumn{6}{|c|}{ Non-ICU patients } & \multicolumn{6}{|c|}{ ICU patients } \\
\hline & $\begin{array}{l}\mathrm{N} \text { of } \\
\text { studies }\end{array}$ & $\begin{array}{l}\mathrm{N} \text { of } \\
\text { Patients }\end{array}$ & $\begin{array}{l}\text { N with } \\
\text { dysfunction }\end{array}$ & Prevalence, $\%$ & $95 \% \mathrm{Cl}$ & $I^{2}, \%$ & $\begin{array}{l}\mathrm{N} \text { of } \\
\text { studies }\end{array}$ & $\begin{array}{l}\mathrm{N} \text { of } \\
\text { patients }\end{array}$ & $\begin{array}{l}\mathrm{N} \text { with } \\
\text { dysfunction }\end{array}$ & Prevalence, $\%$ & $95 \% \mathrm{Cl}$ & $\mathrm{I}^{2}$, \\
\hline ARDS & 34 & 26644 & 5555 & 27.6 & $21.6-34.5$ & 99 & 25 & 3661 & 2124 & 88.3 & 79.7-93.5 & \\
\hline Shock & 23 & 16455 & 1775 & 7.2 & $4.6-11.0$ & 96 & 15 & 2752 & 803 & 34.4 & $23.9-46.7$ & \\
\hline $\begin{array}{l}\text { Renal } \\
\text { dysfunction }\end{array}$ & 36 & 31898 & 4700 & 11.7 & 7.7.17.3 & 99 & 19 & 2912 & 673 & 22.0 & $15.0-31.0$ & $\begin{array}{l}90 \\
0 \\
0 \\
0 \\
0\end{array}$ \\
\hline Coagulopathy & 34 & 14615 & 1530 & 13.0 & $10.1-16.5$ & 95 & 21 & 3398 & 501 & 12.5 & $7.7-19.8$ & \\
\hline $\begin{array}{l}\text { Liver } \\
\text { dysfunction }\end{array}$ & 18 & 10977 & 690 & 6.8 & $4.4-10.3$ & 94 & 14 & 2566 & 411 & 18.1 & $9.1-32.7$ & 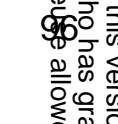 \\
\hline $\begin{array}{l}\text { CNS } \\
\text { dysfunction }\end{array}$ & 13 & 29548 & 4856 & 5.4 & 3.3-8.5 & 98 & 4 & 1520 & 57 & 4.7 & $1.3-16.2$ & 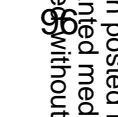 \\
\hline $\begin{array}{l}\underline{A b} \\
\text { un }\end{array}$ & viatic & ARDS & respiratc & istress synd & ; $\mathrm{Cl} \mathrm{co}$ & enc & iterva & JS cer & iervous sy & 7; ICU intensi & sare & 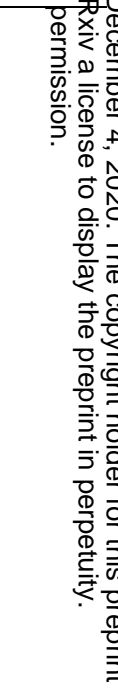 \\
\hline
\end{tabular}


Table 2. Summary of the pooled estimates of prevalence of organ replacement among adult patients hospitalized in the Intensive Care Unit (ICU) and non-ICU wards.

\begin{tabular}{|c|c|c|c|c|c|c|c|c|c|c|c|c|}
\hline \multirow[b]{2}{*}{$\begin{array}{l}\text { Type of } \\
\text { replacement }\end{array}$} & \multicolumn{6}{|c|}{ Non-ICU patients } & \multicolumn{5}{|c|}{ ICU patients } & \multirow{2}{*}{ 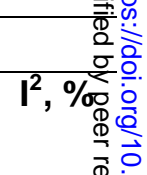 } \\
\hline & $\begin{array}{l}\mathrm{N} \text { of } \\
\text { studies }\end{array}$ & $\begin{array}{l}\mathrm{N} \text { of } \\
\text { patients }\end{array}$ & $\begin{array}{l}\mathrm{N} \text { with } \\
\text { replacement }\end{array}$ & Prevalence, \% & $95 \% \mathrm{Cl}$ & $I^{2}, \%$ & \begin{tabular}{|l|}
$\mathbf{N}$ of \\
studies
\end{tabular} & $\begin{array}{l}\mathrm{N} \text { of } \\
\text { patients }\end{array}$ & $\begin{array}{l}\mathrm{N} \text { with } \\
\text { replacement }\end{array}$ & Prevalence, $\%$ & $95 \% \mathrm{Cl}$ & \\
\hline NIMV & 25 & 41519 & 4185 & 10.6 & $7.7-14.5$ & 96 & 20 & 3448 & 849 & 31.3 & $20.4-44.6$ & 97 市흥 \\
\hline MV & 43 & 65084 & 7714 & 11.1 & $9.3-13.3$ & 98 & 27 & 4495 & 1881 & 57.3 & $44.1-69.5$ & 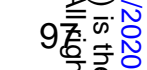 \\
\hline ECMO & 18 & 21631 & 191 & 1.1 & $0.7-1.8$ & 82 & 17 & 3032 & 144 & 6.7 & $3.5-12.6$ & 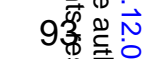 \\
\hline $\begin{array}{l}\text { CRRT/ } \\
\text { dialysis }\end{array}$ & 16 & 9048 & 283 & 3.1 & $1.9-5.0$ & 90 & 14 & 2706 & 336 & 14.1 & $9.5-20.3$ & 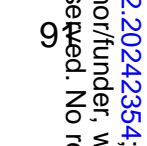 \\
\hline $\begin{array}{l}\mathrm{Ak} \\
\mathrm{IC}\end{array}$ & $\begin{array}{l}\text { reviati } \\
\text { intens }\end{array}$ & $\begin{array}{l}\text { : Cl co } \\
\text { care u }\end{array}$ & $\begin{array}{l}\text { ence interv } \\
\text { MV mechar }\end{array}$ & $\begin{array}{l}\text { SRRT continu } \\
\text { I ventilation; }\end{array}$ & $\begin{array}{l}\text { us renal re } \\
\text { MV non-in }\end{array}$ & sive $r$ & $\begin{array}{l}\text { therap } \\
\text { chanica }\end{array}$ & $\begin{array}{l}\text { ECMO e } \\
\text { 'entilatio }\end{array}$ & $\begin{array}{l}\text { tracorporeal } \\
\text {; N number. }\end{array}$ & nbrane oxygen & tion; & 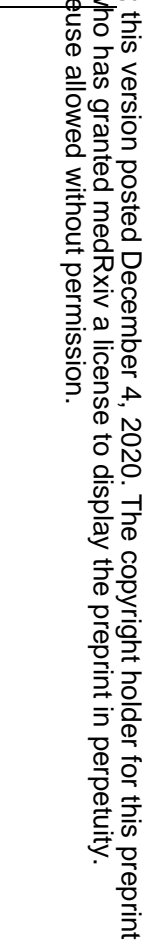 \\
\hline
\end{tabular}


Records identified through database searching $(n=1,903)$

PubMed: 325

Cochrane: 501

Google Scholar: 1,077

\section{Additional records} identified through other sources $(n=0)$

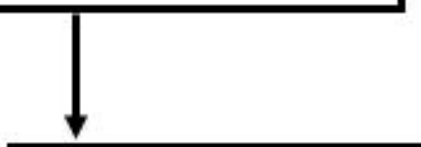

Records excluded by title

$$
\text { ( } n=1,464 \text { ) }
$$

Records after duplicates removed ( $n=1,702)$

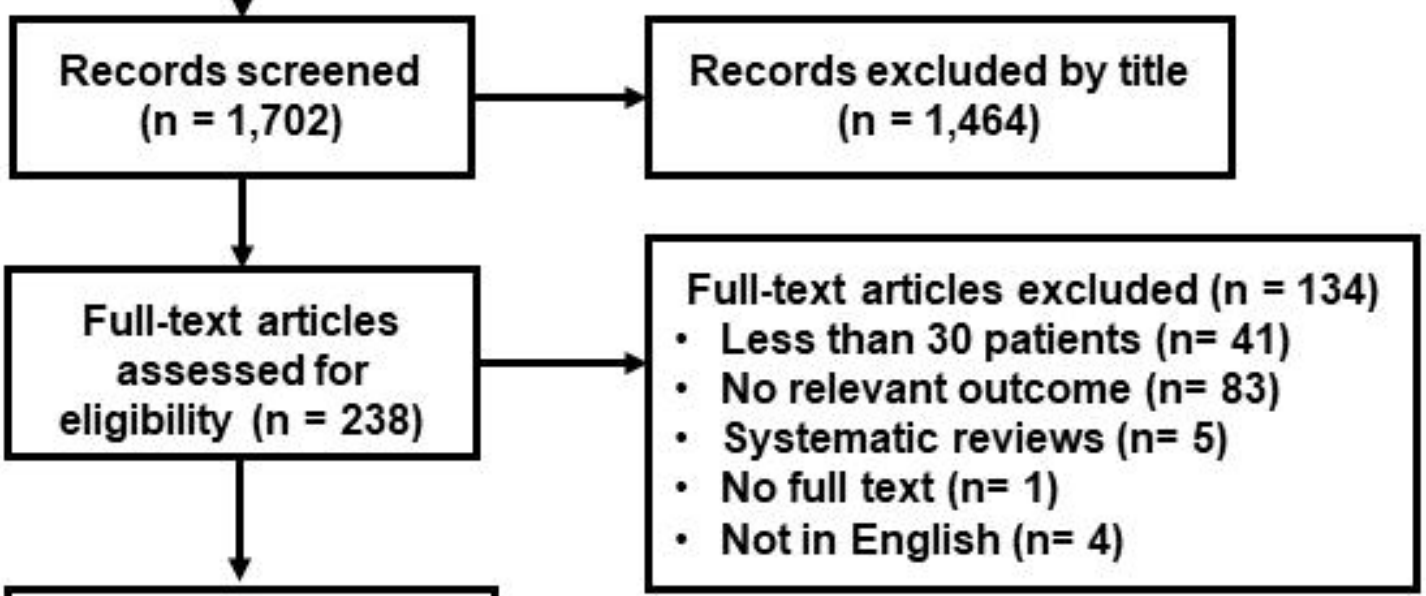

Studies included in qualitative synthesis

$$
\text { ( } n=104 \text { ) }
$$

Studies included in quantitative synthesis $(n=104)$ 


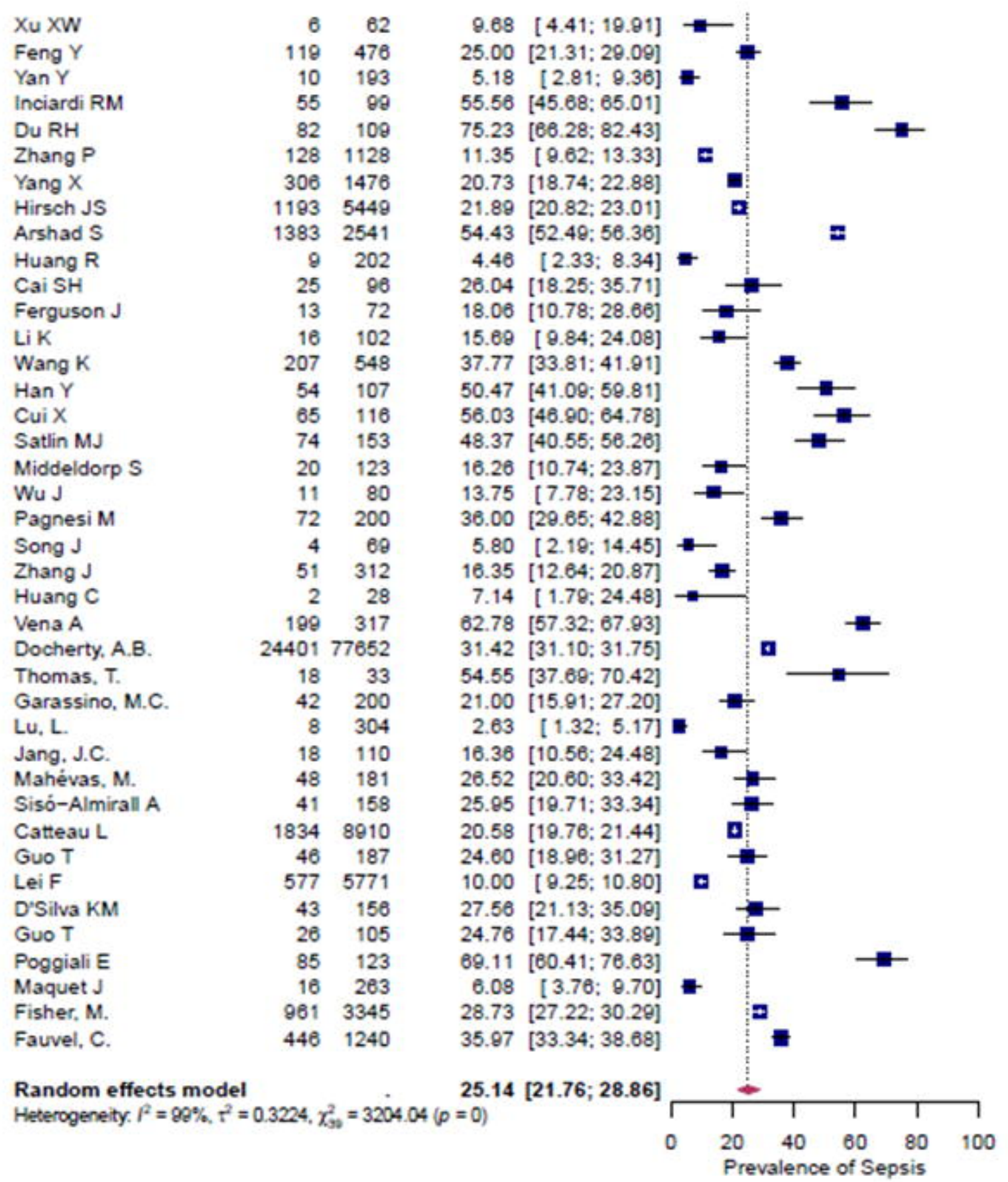

Yang $X$

Helms $J$

Tang $X$

Antinoris

Mitra AR

Kox M
Xu J

Huang M

Bolondi

Middeldorp S

Huang $C$

Cummings, M.J.

Yuan, $\mathrm{Y}$.

Lecronier, M.

Halvatsiotis P

Chen $Y$

Azoulay E

Grieco DL

Cao J

Krause M

Shah A

Yang $X$

Auld SC

Li L

Della-Torre E

Patel, B.V.

Nadeem, A

$\begin{array}{rr}52 & 52 \\ 150 & 150 \\ 73 & 73 \\ 35 & 35 \\ 101 & 117 \\ 46 & 46 \\ 180 & 239 \\ 41 & 60 \\ 31 & 31 \\ 80 & 154 \\ 7 & 75 \\ 11 & 13 \\ 257 & 257 \\ 169 & 226 \\ 80 & 80 \\ 39 & 40 \\ 82 & 90 \\ 39 & 51 \\ 285 & 379 \\ 70 & 92 \\ 30 & 30 \\ 153 & 244 \\ 70 & 93 \\ 187 & 187 \\ 45 & 59 \\ 163 & 217 \\ 99 & 103 \\ 56 & 56 \\ 39 & 39 \\ 41 & 55 \\ 85 & 185 \\ & \end{array}$

100.00 [86.63; 99.94]

100.00 [94.93; 99.98 ]

100.00 [90.11; 99.96$]$

100.00 [81.33; 99.91$]$

$86.32[78.84 ; 91.45]$

$100.00[85.14 ; 99.93]$

$75.31 \quad[69.45 ; 80.37]$

68.33 [55.61; 78.80$]$

100.00 [79.40; 99.90$]$

$51.95[44.07 ; 59.73$

$9.33[4.51 ; 18.31]$

84.62 [54.94: 96.13$]$

$84.62[54.94 ; 96.13]$
$100.00[96.98 ; 99.99]$

$74.78[68.71 ; 80.01]$

$74.78[68.71,80.01]$

$100.00[90.90 ; 99.96]$

91.11 [84.27, 99.65]

91.11 [83.22, 95.49]

$76.47[62.99 ; 86.12]$

$75.20[70.60,79.29]$

$76.09[66.34 ; 83.71]$

100.00 [78.86; 99.90$]$

$62.70[56.47 ; 68.55]$

$75.27[65.52 ; 82.98]$

100.00 [95.90; 99.98 ]

$76.27[63.83 ; 85.41]$

$75.12[68.93 ; 80.42]$

96.12 [90.11; 98.53 ]

$100.00[87.47 ; 99.95]$

$100.00[82.92 ; 99.92]$

$74.55[61.49 ; 84.31]$
$45.95[38.90 ; 53.16$

Random effects model

\begin{tabular}{l}
$03.79[78.13 ; 88.20]$ \\
\hline
\end{tabular} $<0.01)$

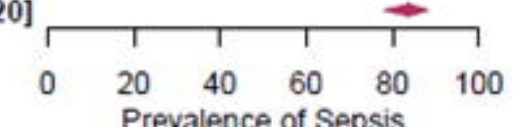

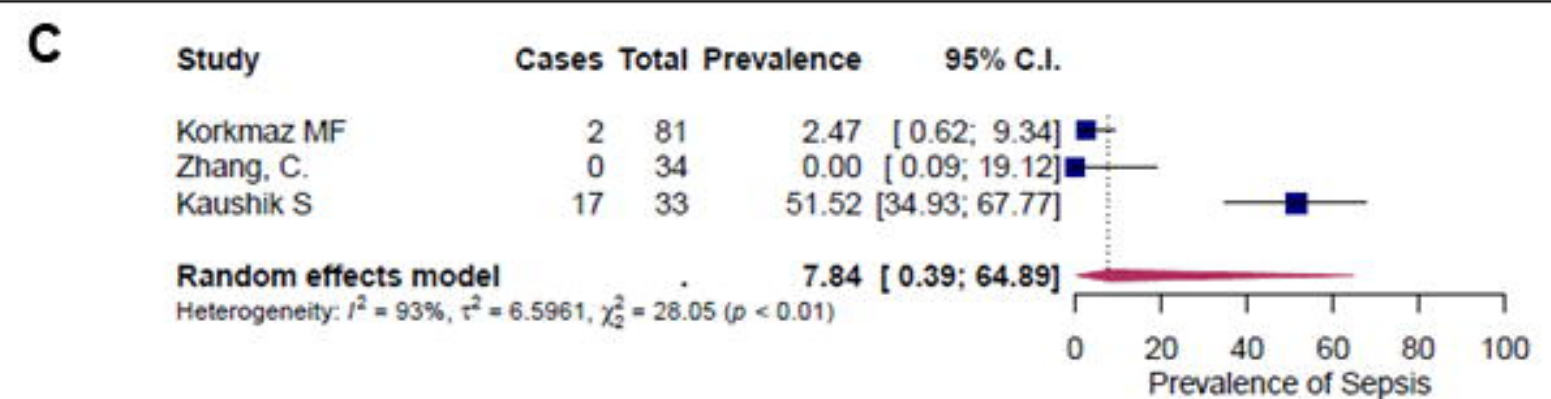


Study

XuXW

Yan Y

Inciardi RM

DuRH

Hirsch JS

Arshad S

Huang $R$

Ferguson J

Ebinger JE

Satlin MJ

Bolondi $G$

ZouX

Pagnesi M

Huang $\mathrm{C}$

Vena A

Demelo-Rodriguez, $P$.

Docherty, A.B.

Garassino, M.C.

Zhao, M.

Hur, K.

Yang, $K$.

Jang, J.C.

Xu,P.P.

Mahévas, M.

Zhang, $Y$.

Wan, Y.

Huang, S.

Mato $\mathrm{A}$

Turcotte JJ

Ip A

Kim MK

Catteau L

D'Silva KM

Fisher, M.

Fauvel, C.

Gatti, A.

Scarfo, L.
Cases Total Prevalence $\quad 95 \%$ C.I.

$\begin{array}{rr}1 & 62 \\ 92 & 193 \\ 12 & 99 \\ 51 & 109 \\ 1395 & 5449 \\ 614 & 2541 \\ 11 & 202 \\ 21 & 72 \\ 75 & 212 \\ 54 & 153 \\ 31 & 31 \\ 154 & 154 \\ 7 & 200 \\ 13 & 41 \\ 65 & 317 \\ 16 & 156 \\ 3001 & 20133 \\ 13 & 200 \\ 63 & 1000 \\ 161 & 486 \\ 30 & 205 \\ 13 & 110 \\ 46 & 703 \\ 41 & 181 \\ 7 & 166 \\ 35 & 230 \\ 51 & 310 \\ 38 & 178 \\ 36 & 117 \\ 150 & 2512 \\ 130 & 1082 \\ 488 & 8910 \\ 18 & 156 \\ 438 & 3345 \\ 551 & 2878 \\ 6 & 30 \\ 39 & 190\end{array}$

1.61

$47.67[40.71 ; 54.71]$

$12.12 \quad[7.01 ; 20.14]$

$46.79[37.64 ; 56.16]$

$25.60[24.46 ; 26.78]$

$24.16[22.54 ; 25.87]$

$5.45 \quad[3.04 ; 9.56]$

$29.17[19.85 ; 40.63]$

$35.38[29.23 ; 42.04]$

35.29 [28.14; 43.18]

$100.00[79.40 ; 99.90]$

$100.00[95.06 ; 99.98]$

$3.50 \quad[1.68 ; 7.16]$

$31.71[19.39 ; 47.27]$

$20.50[16.41 ; 25.31]$

$10.26 \quad[6.38 ; 16.09]$

$14.91[14.42 ; 15.40]$

$6.50 \quad[3.81 ; 10.87]$

$6.30 \quad[4.95 ; 7.98]$

$33.13[29.08 ; 37.44]$

$14.63[10.42 ; 20.16]$

$11.82 \quad[6.99 ; 19.30]$

$6.54 \quad[4.94 ; 8.63]$

22.65 [17.13; 29.32]

$4.22 \quad[2.02 ; 8.58]$

$15.22[11.13 ; 20.46]$

$16.45[12.73 ; 21.00]$

21.35 [15.94; 27.98]

30.77 [23.08; 39.69]

$5.97 \quad[5.11 ; 6.97]$

12.01 [10.21; 14.09]

$5.48 \quad[5.02 ; 5.97]$

$11.54 \quad[7.39 ; 17.57]$

13.09 [11.99; 14.28]

$19.15[17.75 ; 20.62]$

$20.00 \quad[9.27 ; 37.95]$

$20.53[15.37 ; 26.86]$

$16.81[13.95 ; 20.13]$

Random effects model

Heterogeneity: $I^{2}=98 \%, \tau^{2}=0.3966, \chi_{36}^{2}=2029.29(p=0)$
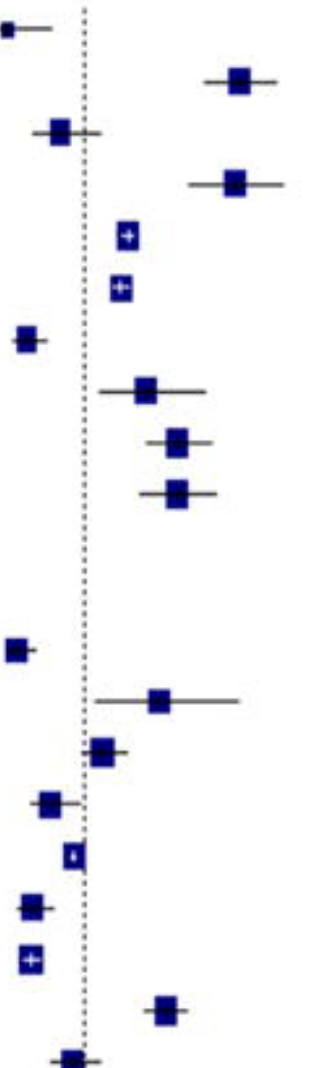

(t)

I

a

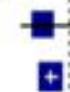

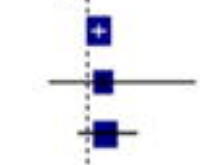

